\title{
Microbial Metabolism of Alicyclic Hydrocarbons: Cyclohexane Catabolism by a Pure Strain of Pseudomonas sp.
}

\author{
By MURRAY S. ANDERSON,* ROBERTA A. HALL AND \\ MARTIN GRIFFIN \\ Department of Life Sciences, Trent Polytechnic, Nottingham NG1 $4 B U$
}

(Received 12 February 1980; revised 11 April 1980)

\begin{abstract}
A micro-organism capable of growth on cyclohexane as the sole carbon source has been isolated from soil of an ash wood; the organism has been identified as a pseudomonad. Growth, respiration and enzymic studies with the organism are consistent with an oxidation route for cyclohexane proceeding via cyclohexanol, cyclohexanone, 6 -caprolactone, 6hydroxycaproate and adipate. Cell-free extracts of the organism grown on cyclohexane demonstrated cyclohexane hydroxylase activity which was found to be very labile, dependent on molecular oxygen and specific for NADH; the product of this reaction was identified as cyclohexanol.
\end{abstract}

\section{INTRODUCTION}

One of the most abundant natural cycloalkanes, cyclohexane, occurs in crude oil and as a structural component of many interesting and important molecules including cyclic terpenes, sterols and carotenoids. The growth of micro-organisms on cyclohexane was first reported by Imelik (1948); however, the recalcitrant nature of this compound was later demonstrated by the unsuccessful attempts of other groups to substantiate these results (Ooyama \& Foster, 1965; Tonge \& Higgins, 1974; Donoghue et al., 1976). The possibility that cyclohexane was metabolized via a co-oxidation route, through a cycloalkanone, was proposed by Beam \& Perry (1973) and de Klerk \& Van der Linden (1974).

More recent work by Stirling et al. (1977) has demonstrated the ability of a Nocardia sp. to grow on cyclohexane as the sole source of carbon. The route of oxidation was tentatively identified as cyclohexanol $\rightarrow$ cyclohexanone $\rightarrow \epsilon$-caprolactone $\rightarrow 6$-hydroxycaproate. This route confirms the findings of Donoghue et al. (1976) working with substituted cycloalkanes, but contrasts with the report of Murray et al. (1974) who suggested that the metabolism of cyclohexanone required a further hydroxylation step to 2-hydroxycyclohexanone before ring cleavage occurred.

The metabolism of cyclohexane by a pure strain of Pseudomonas has been elucidated in detail and is presented in this report.

\section{METHODS}

Isolation, maintenance and culture of the cyclohexane-degrading micro-organism. A bacterium capable of growth on cyclohexane was first isolated from a soil sample of a local ash wood by classical enrichment techniques using cyclohexane vapour as sole carbon source. The bacterium, a Pseudomonas sp., was maintained in a liquid medium containing $\left(\mathrm{g} \mathrm{l}^{-1}\right): \mathrm{KH}_{2} \mathrm{PO}_{4}, 2.0 ; \mathrm{Na}_{2} \mathrm{HPO}_{4}, 4 \cdot 0 ;\left(\mathrm{NH}_{4}\right)_{2} \mathrm{SO}_{4}, 2.0 ; \mathrm{FeCl}_{3} .6 \mathrm{H}_{2} \mathrm{O}$, $0.01 ; \mathrm{NaCl}, 0.1 ; \mathrm{MgCl}_{2} .6 \mathrm{H}_{2} \mathrm{O}, 0.4 ; \mathrm{CaCl}_{2} .2 \mathrm{H}_{2} \mathrm{O}, 0.01$; yeast extract, 0.1 . Following sterilization (15 min, $\left.120^{\circ} \mathrm{C}\right) 250 \mathrm{ml}$ conical flasks, containing $100 \mathrm{ml}$ medium, were inoculated with microbial suspension (10 ml) and stoppered with a sterile silicone bung. Cyclohexane was added $(0.2 \mathrm{ml})$ and flasks were incubated at 
$30^{\circ} \mathrm{C}$ on a rotary shaker $\left(200 \mathrm{rev}\right.$. $\left.\mathrm{min}^{-1}\right)$. The flasks were aerated every $3 \mathrm{~d}$ by replacing the silicone bungs with sterile cotton wool bungs for $8 \mathrm{~h}$. When large quantities of bacteria were required, cells were grown in batch culture ( 51$)$ in an impeller-agitated fermenter (LH Engineering, Stoke Poges, Bucks.). Cyclohexane was supplied as a vapour in the main air supply $\left(21 \mathrm{~min}^{-1}\right)$.

Preparation of cell suspensions. The organism was harvested by centrifugation $(10000 \mathrm{~g}$ for $15 \mathrm{~min}$ at $4{ }^{\circ} \mathrm{C}$ ), washed twice in $20 \mathrm{mM}-\mathrm{KH}_{2} \mathrm{PO}_{4} / \mathrm{Na}_{2} \mathrm{HPO}_{4}$ buffer $\mathrm{pH} 7.1$ and then resuspended in the same buffer ( $1.5 \times$ volume of bacterial paste).

Preparation of cell-free extracts. Washed cell suspensions were disrupted by ultrasonication (MSE $100 \mathrm{~W}$ ultrasonic disintegrator) for a total of $3 \mathrm{~min}\left(15 \mathrm{~s}\right.$ bursts at $\left.4^{\circ} \mathrm{C}\right)$. For the isolation of cyclohexane hydroxylase, cell suspensions contained $10 \%(v / v)$ glycerol and were pre-cooled to $0{ }^{\circ} \mathrm{C}$. Cell debris was removed by centrifugation $(20000 \mathrm{~g}$ for $10 \mathrm{~min}$ ) and the supernatant was used as a cell-free extract.

Measurement of oxygen uptake. The oxidation of substrates by whole cells was measured using an oxygen electrode (Rank Bros, Bottisham, Cambs.) at $30^{\circ} \mathrm{C}$. Incubation mixtures contained (in $3 \mathrm{ml}$ ) $60 \mu \mathrm{mol}$

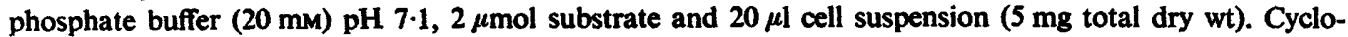
hexane. methylcyclohexane, cyclohexene and cyclohexene oxide $(2 \mu \mathrm{l})$ were added directly to the incubation mixtures.

Enzyme assays. Cyclohexane hydroxylase activity was assayed by measuring the NADH-dependent oxidation of cyclohexane in the oxygen electrode. Reaction mixtures contained (in $3 \mathrm{ml}$ ) $60 \mu \mathrm{mol}$ phosphate buffer ( $20 \mathrm{~mm}$ ) pH 7.1, 1.0 to $1.5 \mathrm{mg}$ protein, $20 \mu \mathrm{mol}$ substrate and $1 \mu \mathrm{mol} \mathrm{NADH}$.

Cyclohexanol dehydrogenase activity was assayed by the method of Donoghue et al. (1976). Reaction mixtures contained (in $1 \mathrm{ml}$ ) $20 \mu \mathrm{mol}$ glycine/ $\mathrm{NaOH}$ buffer $(20 \mathrm{mM}) \mathrm{pH} 10.6,0.2 \mu \mathrm{mol} \mathrm{NAD}+0.5 \mathrm{mg}$ protein and $0.5 \mu \mathrm{mol}$ cyclohexanol. The rate of $\mathrm{NAD}^{+}$reduction was recorded by measuring the increase in absorbance at $340 \mathrm{~nm}$ using a Perkin Elmer SP1800 recording spectrophotometer. Cyclohexanone monooxygenase was assayed by recording the cyclohexanone-dependent oxidation of NADPH at $340 \mathrm{~nm}$ using the method of Norris \& Trudgill (1971). Reaction mixtures contained (in $1 \mathrm{ml}$ ) $20 \mu \mathrm{mol}$ sodium acetate buffer (20 mM) pH 4.8, 0.1 to $0.5 \mathrm{mg}$ protein, $0.3 \mu \mathrm{mol} \mathrm{NADPH}$ and $0.25 \mu \mathrm{mol}$ cyclohexanone. Caprolactone hydrolase was assayed by the method of Norris \& Trudgill (1971). Incubation mixtures contained (in $2 \mathrm{ml}$ ) $1 \mathrm{mmol}$ Tris $/ \mathrm{HCl}$ buffer $(20 \mathrm{mM}) \mathrm{pH} \mathrm{8 \cdot 0,0.2} \mathrm{mg}$ protein and $10 \mu \mathrm{mol} \epsilon$-caprolactone.

6-Hydroxycaproate dehydrogenase activity was assayed by measuring the increase in absorbance at $340 \mathrm{~nm}$ due to $\mathrm{NAD}^{+}$reduction using the method of Donoghue et al. (1976). Reaction mixtures contained (in $1 \mathrm{ml}) 20 \mu \mathrm{mol}$ glycine $/ \mathrm{NaOH}$ buffer (20 mM) pH $10.4,0.5$ to $1.0 \mathrm{mg}$ protein, $0.3 \mu \mathrm{mol} \mathrm{NAD}{ }^{+}$and $2 \mu \mathrm{mol}$ 6-hydroxycaproate.

Estimation of enzyme pH optima. The effect of $\mathrm{pH}$ on enzyme-catalysed reactions was determined by using five different buffer mixtures, each at a concentration of $20 \mathrm{mM}$, covering the pH range of 4 to 11 . Buffers used were: sodium acetate, sodium citrate, phosphate, Tris/ $\mathrm{HCl}$ and glycine/ $\mathrm{NaOH}$. A pH overlap was allowed between each buffer change.

Identification and determination of reaction products. Cyclohexanol and cyclohexanone were detected by gas-liquid chromatography (g.l.c.) (Perkin Elmer F33) using a 2 m column packed with $15 \%$ (w/w) Carbowax on Chromosorb W. Incubation mixtures were acidified with $2 \mathrm{M}-\mathrm{HCl}$ and precipitated protein was removed by centrifugation. The supernatants were extracted with diethyl ether and concentrated extracts were used for g.l.c.; retention times of products were compared with those of authentic standards. $e$-Caprolactone was determined by the procedure of alkaline hydroxamate formation followed by acidification conversion to the ferric hydroxamate and measurement of $A_{330}$ as described by Cain (1961). For thin-layer chromatography (t.l.c.), reaction products were converted to their hydroxamic acid esters, extracted with ethyl acetate and identified by comparison with the derivative of authentic $\epsilon$-caprolactone in the three t.l.c. systems of Griffin \& Trudgill (1972). 6-Hydroxycaproate and adipic acid were extracted from acidified incubation mixtures with diethyl ether and identified by comparison with authentic standards in the t.l.c. systems described by Donoghue et al. (1976).

Preparation of 6-hydroxycaproate. 6-Hydroxycaproate was prepared by alkaline hydrolysis of 6 -caprolactone as described by Norris \& Trudgill (1971).

\section{RESULTS}

\section{Isolation and growth studies}

Soil samples from various areas around Nottingham were examined for cyclohexaneutilizing micro-organisms and several mixed cultures proved capable of sustained growth on this substrate. Purification of one of these mixed cultures revealed that two organisms were present, identified as a Pseudomonas sp. and a Microbacterium sp., but only the pseudo- 
Table 1. Oxidation of various substrates by whole cell suspensions of Pseudomonas sp. grown on cyclohexane and succinate

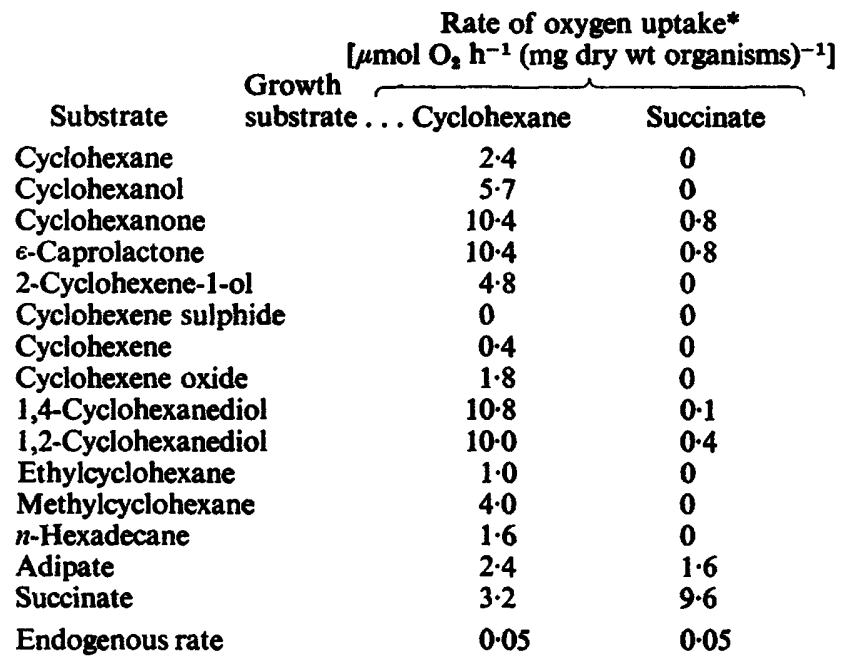

* Calculated by subtracting the endogenous rate from the actual rate with substrate.

monad was capable of growth on cyclohexane as the sole carbon source. The Microbacterium sp. was found to be a contaminant of the commercially available cyclohexane used and its full removal was only achieved by washing the cyclohexane in sodium hypochlorite (50:50, v/v), distilling off the organic layer and then filter-sterilizing. The Microbacterium sp. could not grow on cyclohexanol and cyclohexanone. The pseudomonad was found to be capable of growth on cyclohexane, cyclohexanol, cyclohexanone, methylcyclohexane, cyclohexene oxide, $n$-hexadecane, benzene, $\epsilon$-caprolactone, adipate and succinate. When grown on cyclohexane the organism had an adaptation period of 16 to $20 \mathrm{~h}$ with a mean generation time of $8 \mathrm{~h}$.

\section{Oxidation of substrates by whole cells}

Washed cell suspensions of the pseudomonad grown on cyclohexane and succinate were investigated for their ability to oxidize cyclohexane and a variety of possible catabolic intermediates (Table 1). The organism was capable of oxidizing a number of cyclohexane analogues when grown on cyclohexane but succinate-grown cells had a limited ability for substrate utilization, only oxidizing cyclohexanone, $\epsilon$-caprolactone, 1,2-cyclohexanediol and adipate at very slow rates.

\section{Oxidation of substrates by cell-free extracts}

The incubation of cell-free extracts with cyclohexane and reduced pyridine nucleotides failed to stimulate increased oxygen consumption following various methods of cell disruption. Only when the disruption medium contained $10 \%(\mathrm{v} / \mathrm{v})$ glycerol prior to ultrasonication did an NADH-dependent consumption of oxygen occur in the presence of cyclohexane. No increase in oxygen consumption occurred over the normal NADPH oxidase activity when extracts were incubated with NADPH and cyclohexane. Cell extracts lost cyclohexane hydroxylase activity very quickly, and when stored at $4{ }^{\circ} \mathrm{C}$ lost all activity over a period of $24 \mathrm{~h}$. The product of cyclohexane hydroxylase activity was identified as cyclohexanol by the procedures outlined in Methods. The activities and pH optima of a range of enzymes from cell-free extracts of cyclohexane-grown cells are listed in Table 2.

Oxidation of cyclohexanol. Extracts of the cyclohexane-grown Pseudomonas sp. catalysed 
Table 2. Activity and pH optima of various enzymes involved in cyclohexane oxidation from cell-free extracts of Pseudomonas sp. grown on cyclohexane

\begin{tabular}{lrc}
\multicolumn{1}{c}{ Enzyme } & Activity \\
Cyclohexane hydroxylase & {$\left[\mu \mathrm{mol} \mathrm{min}^{-1}(\mathrm{mg} \text { protein) })^{-1}\right]$} & $\mathrm{pH}$ optimum \\
Cyclohexanol dehydrogenase & 0.01 & $\mathrm{NT}$ \\
Cyclohexanone monooxygenase & 0.04 & 10.6 \\
E-Caprolactone hydrolase & 0.66 & 4.8 \\
6-Hydroxycaproate dehydrogenase & 15.10 & 8.0 \\
& $\mathrm{NT}$, Not tested. & 10.4
\end{tabular}

Table 3. Stoicheiometry of the NADPH and oxygen requirement for the oxidation of cyclohexanone in cell-free extracts of Pseudomonas sp.

\section{Stoicheiometry of NADPH requirement}

The reaction mixture contained (in $1 \mathrm{ml}$ ) $20 \mu \mathrm{mol}$ phosphate buffer pH 7.1, 0.1 to $0.5 \mathrm{mg}$ protein from $20000 \mathrm{~g}$ supernatant and $0.3 \mu \mathrm{mol}$ NADPH. Reactions, at $30^{\circ} \mathrm{C}$, were started by addition of cyclohexanone and the decrease in absorbance at $340 \mathrm{~nm}$ was followed until it ceased.

Cyclohexanone added
$(\mu \mathrm{mol}) \mathrm{A}$
0.05
0.10
0.15
0.20

$\begin{array}{cc}\text { NADPH oxidized } & \text { Ratio } \\ (\boldsymbol{\mu} \text { mol }) \mathrm{B} & \text { A/B } \\ 0.045 & 0.90 \\ 0.10 & 1.00 \\ 0.14 & 0.93 \\ 0.19 & 0.95\end{array}$

Stoicheiometry of oxygen requirement

The oxygen electrode contained (in $3 \mathrm{ml}$ ) $60 \mu \mathrm{mol}$ phosphate buffer pH 7.1, 2 to $5 \mathrm{mg}$ protein from $20000 \mathrm{~g}$ supernatant and $1 \mu \mathrm{mol}$ NADPH. The reactions were carried out at $30^{\circ} \mathrm{C}$ until all available cyclohexanone had been oxidized.

Cyclohexanone added
$(\mu \mathrm{mol}) \mathrm{A}$
0.15
0.30
0.45
0.60

$\begin{array}{cc}\text { O }_{2} \text { consumed } & \text { Ratio } \\ (\mu \mathrm{mol}) \mathrm{B} & \text { A/B } \\ 0.12 & 0.80 \\ 0.30 & 1.00 \\ 0.48 & 1.06 \\ 0.54 & 0.90\end{array}$

the stoicheiometric reduction of $\mathrm{NAD}^{+}$in the presence of cyclohexanol at $\mathrm{pH} 10 \cdot 6$. The product of this reaction co-chromatographed with authentic cyclohexanone on g.l.c.

Oxidation of cyclohexanone. The activity of cyclohexanone monooxygenase was demonstrated in cell-free extracts and found to be specific for NADPH. Investigations into the reaction stoicheiometry of this enzyme (Table 3 ) demonstrated that the oxidation of $1 \mu \mathrm{mol}$ cyclohexanone was accompanied by the consumption of $0.95 \mu \mathrm{mol}$ NADPH and $0.94 \mu \mathrm{mol}$ oxygen, which is close to that theoretically required for a mixed function oxygenase. When cell-free extracts were incubated with NADPH and cyclohexanone the product of the reaction was identified as 6-hydroxycaproate by the t.l.c. systems described by Donoghue et al. (1976). The presence of a lactone hydrolase converting the product of the oxygenase reaction to the corresponding hydroxy acid was investigated and confirmed (Table 2). This finding is in agreement with those of Stirling et al. (1977) for a cyclohexane-grown Nocardia sp. and Donoghue \& Trudgill (1975) for cyclohexanol-grown Acinetobacter NCIB 9871.

Identification of e-caprolactone as the product of cyclohexanone monooxygenase. Incubation of the $20000 \mathrm{~g}$ supernatant with $12 \mu \mathrm{mol}$ cyclohexanone, $13 \mu \mathrm{mol} \mathrm{NADPH}, 60 \mu$ mol sodium acetate buffer $(20 \mathrm{mM}) \mathrm{pH} 4.8$, and in the presence of $0.6 \mu \mathrm{mol}$ of the esterase inhibitor Dichlorvos (2,2-dichlorovinyldimethylphosphate) (total vol. $3 \mathrm{ml}$ ) yielded a product that when converted into its hydroxamic acid ester co-chromatographed with the derivative of $\epsilon$-caprolactone on the t.l.c. systems described in Methods. The inclusion of Dichlorvos in the 
incubation mixture had no inhibitory effect on cyclohexanone monooxygenase but gave a $96 \%$ inhibition of the $\epsilon$-caprolactone hydrolase when compared with control reaction mixtures.

Oxidation of 6-hydroxycaproate to adipate. Incubation of cell-free extracts with 6hydroxycaproate and $\mathrm{NAD}^{+}$under anaerobic conditions yielded a limited and nonstoicheiometric reduction of $\mathrm{NAD}^{+}$monitored by an increase in absorbance at $340 \mathrm{~nm}$. Addition of NADP+ to the reaction mixture did not cause any further increase in $A_{340}$. The product of 6-hydroxycaproate oxidation, incubated under aerobic conditions thereby mediating NADH oxidase activity, co-chromatographed with adipic acid in the t.l.c. systems described by Donoghue et al. (1976).

\section{DISCUSSION}

The results reported here show the ability of a pure culture of a bacterium to utilize cyclohexane as a sole carbon source, a result which supports the findings of Stirling et al. (1977). Initial work involved the isolation of a mixed culture capable of growth on cyclohexane. Subsequent separation of this mixed culture into a Pseudomonas sp. and Microbacterium sp. demonstrated that it was the Pseudomonas sp. which was responsible for the initial oxidation of the cyclohexane ring. This micro-organism could grow on a wide range of hydrocarbons including an aromatic hydrocarbon, a straight-chain hydrocarbon and cyclohexane derivatives. The identification of the micro-organism as a Pseudomonas sp. is of interest and may explain its wide growth specificity considering the broad spectrum of hydrocarbon-degrading plasmids which have been demonstrated in this genus (Chakrabarty, 1976). Cyclohexane oxidation may be yet another example whereby enzymes necessary for its catalysis are coded for by extrachromosomal DNA. The enzyme and respiration studies are consistent with a catabolic route for cyclohexane involving an initial hydroxylation to cyclohexanol and subsequent degradation via cyclohexanone $\rightarrow \epsilon$-caprolactone $\rightarrow$ adipic acid. Studies with cell-free extracts demonstrated no evidence for the presence in the catabolic route of 2-hydroxycyclohexanone or cyclohexan-1,2-dione, intermediates which might suggest direct hydrolytic cleavage of the cyclohexane ring.

The dependence on monooxygenation for ring cleavage has been demonstrated by the presence of a key lactone-forming monooxygenase and a 6 -caprolactone hydrolase. This would support the results of Norris \& Trudgill (1971) and Donoghue \& Trudgill (1975) for the oxidation of cyclohexanol by Nocardia globerula CLI and Acinetobacter NCIB 9871.

The isolation of cyclohexane hydroxylase in cell-free extracts proved difficult to achieve; the enzyme or enzyme complex was found to be very labile and soon lost its activity. This finding was also reported by Stirling et al. (1977) who failed to demonstrate enzyme activity in cell-free extracts of cyclohexane-grown cultures of Nocardia sp. The study of the enzymic mechanism and properties of cyclohexane hydroxylation are presently in progress.

We wish to thank Naamloze Vennootschap, DSM of Heerlen, The Netherlands, for financial support during this project.

\section{REFERENCES}

Beam, H. W. \& Perry, J. J. (1973). Co-metabolism as a factor in microbial degradation of cycloparaffinic hydrocarbons. Archiv für Mikrobiologie 91, 87-90.

CAIN, R. B. (1961). The metabolism of protocatechuic acid by a Vibrio. Biochemical Journal 79, 298-312.

Chakrabarty, A. M. (1976). Plasmids in Pseudomonas. Annual Review of Genetics 10, 7-30.
Donoghue, N. A. \& Trudgild, P. W. (1975). The metabolism of cyclohexanol by Acinetobacter NCIB 9871. European Journal of Biochemistry 60, 1-7.

Donoghue, N. A., Griffin, M., NorRis, D. B. \& TrudGnL, P. W. (1976). The microbial metabolism of cyclohexane and related compounds. Proceedings of the Third International Biodegradation Symposium, pp. 43-56. Essex: Applied Science. 
Griffin, M. \& Trudgill, P. W. (1972). The metabolism of cyclopentanol by Pseudomonas NCIB 9872. Biochemical Journal 129, 595-603.

IMELIK, B. (1948). Oxydation de cyclohexan par Pseudomonas aeruginosa. Comptes rendus hebdomadaire des séances de l'Académie des sciences 226, 2082-2083.

DE KiERK, H. \& VAN DER Linden, A. C. (1974). Bacterial degradation of cyclohexane. Participation of a co-oxidation reaction. Antonie van Leeuwenhoek 40, 7-15.

Murray, J. F., Scheikowski, T. A. \& Macrae, I. C. (1974). Utilization of cyclohexanone and related substances by Nocardia sp. Antonie van Leeuwenhoek 40, 17-24.
Norris, D. B. \& Trudarl, P. W. (1971). The metabolism of cyclohexane by Nocardia globerula CLI. Biochemical Journal 121, 363-370.

OOYAMA, J. \& Foster, J. W. (1965). Bacterial oxidation of cycloparaffinic hydrocarbons. Antonie van Leeuwenhoek 31, 45-65.

Stirling, L. A., Watkinson, R. J. \& Higains, I. J. (1977). Microbial metabolism of alicyclic hydrocarbons: isolation and properties of a cyclohexane-degrading bacterium. Journal of General Microbiology 99, 119-125.

TONGE, G. M. \& Higgins, I. J. (1974). Microbial metabolism of alicyclic hydrocarbons. Growth of Nocardia petroleophila (NCIB 9438) on methyl cyclohexane. Journal of General Microbiology 81, 521-524. 